\title{
The Arabic Book of the Divine Liturgies Printed in 1745 in Iași by Patriarch Sylvester of Antioch
}

\author{
Ioana Feodorov \\ Senior Researcher, Institute for South-East European Studies of the \\ Romanian Academy in Bucharest, Romania \\ ioanafeodorov85@gmail.com
}

\begin{abstract}
The following article focuses on a printed text of the Arabic Book of the Divine Liturgies, produced in 1745 in Iași (Jassy), capital of Moldavia, by Sylvester, the Patriarch of the Greek-Orthodox Church of Antioch (1724-1766), which is comprised, together with a section of a Syriac and Arabic manuscript commentary on some Gospel passages, in MS 15 of the library of Dayr Sayyidat al-Balamand (near Tripoli, Lebanon). It is a rare copy of this early Arabic printed book, whose existence was recently established. The study encloses an outline - based on Romanian, Greek and Arabic sources - of Patriarch Sylvester's printing activity in Iași and Bucharest in 1745-1747, a description of the Book of the Divine Liturgies (Iași, 1745) preserved in the Balamand codex, and comments on the value of this finding for future research on the printing work carried out in the Romanian Principalities, in 1701-1747, for the Arabic-speaking Christians of Ottoman Syria.
\end{abstract}

\section{Keywords}

Arabic-Speaking Christians - Liturgical books - Sylvester of Antioch - Early Arabic printing - Book of the Divine Liturgies - Romanian Principalities - Iași in Moldavia 18th Century

Patriarch Sylvester of Antioch and his journeys to the Romanian lands

In a book published in 2016 that I dedicated to the early Arabic printing achieved by several hierarchs of the Antiochian church in the Romanian 
Principalities, with help from major local printers, I included a chapter about the travels of Patriarch Sylvester of Antioch and his printing work in Iași and Bucharest. ${ }^{1}$ I discussed later, in an article in Revue des études sud-est européennes, ${ }^{2}$ the letters preserved in a miscellany due to Mūsā Țrābulsī, a secretary of Patriarch Sylvester, which he had exchanged with Antiochian hierarchs and monks. The letter collection provides rich information on the Patriarch's travels and activities in the Romanian lands. I present henceforth an overview of these reports, as a background for the comments to follow.

Sylvester was born around 1680 in Cyprus, of Greek parents, Giorgis and Fotini. ${ }^{3} \mathrm{He}$ mentioned their names in the Arabic inscription on an icon that he donated in 1747 to the St Spyridon Monastery of Bucharest, after it was given as a metokion to the Church of Antioch by the Wallachian prince Constantin Mavrocordat (1746). Sylvester's mother was the sister of Patriarch Athanasios III Dabbās, who took care of his education and consecrated him a deacon, an archdeacon, ${ }^{4}$ a priest, and a protosynkellos of the Antiochian Patriarchate. ${ }^{5} \mathrm{He}$ received the tonsure as a monk at Mount Athos, where he studied the art of icon painting according to the Byzantine erminia. He became a Greek-language scholar, utterly knowledgeable in Byzantine culture, and the first in a long series of Greek-speaking Antiochian Patriarchs. ${ }^{6}$

1 I. Feodorov, Tipar pentru creștinii arabi. Antim Ivireanul, Atanasie Dabbās și Silvestru al Antiohiei (Printing for the Arab Christians. Antim the Iberian, Athanasios Dabbās and Sylvester of Antioch), Brăila, 2016. I am preparing an English, improved and enlarged version of this book.

2 I. Feodorov, "New Data on the Early Arabic Printing in the Levant and Its Connections to the Romanian Presses", Revue des études sud-est européennes, LVI, 1-4 (2018), pp. 197-233.

3 According to Le Quien (Oriens Christianus, II, Paris, 1740, p. 776), Sylvester's father was GreekOrthodox, while his mother was Maronite. He was contradicted by other historians, such as

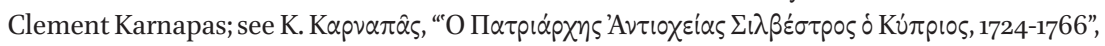
$N \varepsilon \dot{\alpha} \Sigma \iota \omega ́ v, 2$ (1905), pp. 193-194.

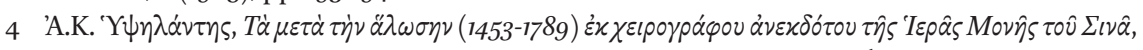
Constantinople, 1870, p. 326; A. Rustum, كنيسة مدينة الله انطايكا العظمى Kanisatmadinat Allāh 'Anțākiya al-'Uzmā, t. III, Beirut, 1928, p. 142.

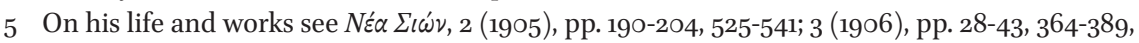
471-485, 6о2-617; 4 (19o6), pp. 49-67, 29o-313, 429-444, 498-514; 5 (1907), pp. 54-69, 361-378,

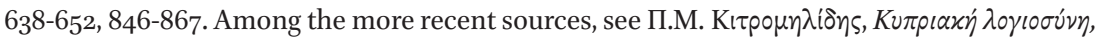

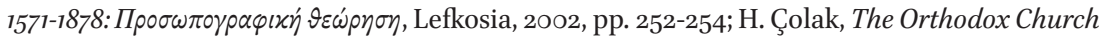
in the Early Modern Middle East: Relations between the Ottoman Central Administration and the Patriarchates of Antioch, Jerusalem and Alexandria, Ankara, 2015, pp. 170-208; B. Nassour,

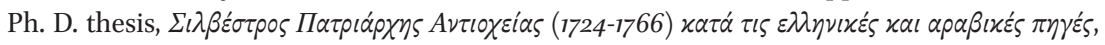
Thessaloniki, 1992 (not published).

6 C.-M. Walbiner, "Bishops and Metropolitans of the Antiochian Patriarchate in the 17th Century: Their Relation with the Muslim Authorities, their Cultural Activities and Their Ethnical Background", ARAM, 9-10 (1998), pp. 587-588; H. Çolak, op. cit., p. 171. 
Sylvester was on Mount Athos ${ }^{7}$ when Athanasios III died, after designating him as his successor. He was called to Damascus, elected a Patriarch by the Antiochian community and rapidly confirmed by a Holy Synod convened in Constantinople in July 1724. His election was backed, among others, by Chrysant Notaras, the Patriarch of Jerusalem (1707-1731), and Nicolae Mavrocordat, the prince of Wallachia. ${ }^{8}$ Also in his favour spoke at the Sultan's court the Grand Dragoman Grigore Ghica (1698-1741). ${ }^{9}$ Sylvester was enthroned by the Ecumenical Patriarch Jeremias III on 8 October 1724 and lead the Antiochian Church until he died, on 13 March 1766. His eparchy included Antioch, Damascus, Aleppo, Tripoli, Sidon, Beirut, Latakia, Payas, Adana, Hamā, Ḥoms, Baalbek, Diyarbekir, Erzurum, Ahizka, and Çildir, with their dependencies. ${ }^{10}$ In addition to other contemporary testimonies, Mūsā Trābulsî's letters reveal that Sylvester was a tireless defender of Orthodoxy and the traditions of the Church of Antioch. ${ }^{11}$ Hasan Çolak, who dedicated a chapter to Patriarch Sylvester in his above-mentioned book, noted that during Sylvester's term there was an "anti-Catholic organisation of the Patriarchate of Antioch".12

Information about Patriarch Sylvester's sojourn in the Romanian Principalities is found in Greek, Arabic, and Romanian sources. I will briefly recall the most significant of them. Obviously, the Forewords signed by Patriarch Sylvester, printed in the few copies of books known to exist in collections around the world, bring the most reliable information..$^{13}$ They trace the presence of the Patriarch in Iași at the time each book was printed, also enclosing sparse notes about his travels. Asad Rustum, the author of one of the most salient Histories of the Church of Antioch, notes that Sylvester travelled through the Romanian

7 Or in Constantinople, according to Le Quien, ibidem.

8 Nicolae Mavrocordat, born in Constantinople on 3 May 1680 (d. 3 September 1730 in Bucharest), was a prince of Moldavia (November 1709 - November 1710 and 1711 - January 1716) and a prince of Wallachia (January - November 1716 and March 1719 - September 1730).

9 The son of Matei Ghica and one of Alexandru Mavrocordat's daughters, Grigore was proficient in several languages, he was an eloquent speaker and a talented writer. He held the position of Grand Dragoman in 1717-1728. He was intermittently a prince of Wallachia in 1728-1735, then of Moldavia, in 1735-1741. Accused of treason, he was executed by the Ottomans.

10 Second berat of investiture, in 1730; see H. Çolak, op. cit., pp. 179-18o.

11 R. Haddad, La Correspondance de Trābulsī, secrétaire du patriarche d'Antioche Sylvestre de Chypre, in: Mémorial Monseigneur Joseph Nasrallah, ed. P. Canivet and J.-P. Rey-Coquais, Damascus, 2006, p. 265. anti-Catholic convictions and actions.

13 I succeeded in collecting four Forewords so far. I intend to annex their English translations to the new version of my above-mentioned book. 
lands for almost 10 years. ${ }^{14}$ The Romanian chronicler Radu Popescu confirms that the Patriarch met prince Nicolae Mavrocordat in Wallachia. ${ }^{15}$ As the prince died on 3 September 1730, this encounter had to have happened before. In 1733 Sylvester was in Wallachia again: Patriarch Parthenios of Jerusalem, who had met him there, mentioned in a homily that "the prince greatly honoured and helped him" (i.e., Sylvester). ${ }^{16}$ The Greek scholar Kesarios Dapontes (1713/1714-1784) witnessed Patriarch Sylvester's presence at the Moldavian court in 1741, when Ioan Mavrocordat was ruling. ${ }^{17}$ A codex preserved in the library of the Greek Patriarchate in Jerusalem contains Greek homilies and letters of Patriarch Sylvester where he comments on his travels to Moldavia and Wallachia in 1742 and $1745 .{ }^{18}$ In 1743 , after the plague struck Damascus, Sylvester left for Moldavia, accompanied again by Mūsā Trābulsī, who gives details about their departure preparations. According to the Syrian historian Mīhāîil Breyk, Sylvester left for Moldavia again in 1744, determined to open an Arabic print press in Iași..$^{19}$ On 3 May 1745, while he was in the capital of Moldavia, prince Ioan Mavrocordat signed an endowment act for the benefit of the Patriarchate of Antioch. ${ }^{20}$ In the autumn of 1746 he was granted by Constantin Mavrocordat, the prince of Wallachia, ${ }^{21}$ the Monastery of St Spyridon in Bucharest with all its assets (kelia, lands, orchards, etc.), as a metokion of the Antiochian Church. He spent there the greater part of the following two years, supervising the repair works on the church (done at the prince's expense), and consecrated

14 A. Rustum, op. cit., p. 146 et seq.

15 R. Popescu, Istoriile domnilor Ţării Româneşti (Chronicles of the Wallachian Princes), ed. C. Grecescu, Bucharest, 1963, pp. 273-274.

$16 \quad$ Néa $\Sigma \iota \dot{\omega} \nu, 5$ (1907), pp. 857, 859.

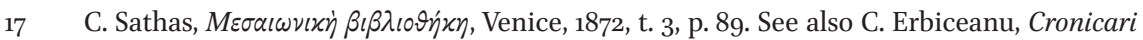
greci care au scris despre români în epoca fanariotă (Greek Chroniclers Who Wrote about the Romanians in the Phanariot Era), Bucharest, 189o, p. 103.

$18 \quad N \varepsilon \dot{\alpha} \alpha \iota \dot{\omega} \nu, 5$ (1907), p. 859.

19 M. Breyk, تاربهُ الشام Tārīh al-Šām, Harīsāā, 1930, p. 27.

20 N. Iorga, Documente grecești privitoare la istoria românilor (Greek Documents Concerning the Romanians' History), vol. XIV. Partea a II-a din Colecția Hurmuzaki, 1716-1777, Bucharest, 1917 , p. 1118, doc. no. 1083. The donations that Patriarch Sylvester obtained while at the Moldavian and Wallachian courts are presented, based on Greek contemporary documents, by Archim. Luca Diaconu in vol. II of his book Mănăstirea „Sfântul Nicolae Domnesc" Popăuți, importantă ctitorie a Moldovei închinată Patriarhiei de Antiohia (The Princely Monastery of "St Nicholas" Popăuți, an Important Foundation of Moldavia Granted to the Antiochian Patriarchy), Iași, 2018, pp. 20 et seq.

21 Brother of Ioan Mavrocordat. He ruled in Wallachia (September 1730-October 1730; October 1731-April 1733; November 1735-September 1741; July 1744-April 1748) and Moldavia (April 1733-November 1735; September 1741-June 1743; April 1748-August 1749). 
it in $1747 .{ }^{22}$ Fr Archim. Policarp Chițulescu, the Director of the Library of the Holy Synod in Bucharest, commented in a recent conference in Alba Iulia (Western Romania) several of Patriarch Sylvester's letters of pardon preserved in Romanian collections. The dates indicated on them bring more precision as to the Patriarch's sojourns in Romanian lands. ${ }^{23}$

\section{2 Patriarch Sylvester's Arabic book-printing activities in the
Romanian Principalities}

Around 1744, the Syrian hierarch obtained the approval of Ioan Mavrocordat, the prince of Moldavia, to print Arabic books in the print press of the St Sava Monastery in Iași, where no Arabic printing tools existed before his arrival. I included in my above-mentioned book a commented list of these books. ${ }^{24}$ Here is a brief reminder: in 1745, Kitāb al-Qundāq or Al-Qūndāq25 (The Book of the Divine Liturgies); in 1746, Kitāb qad̄a al-haqq wa-naql al-șidq etc., the Arabic version of a work against the Pope's primacy authored by Patriarch Nektarios of Jerusalem, ${ }^{26}$ and, bound in the same volume, Risāla muhtașara fí l-radd 'alā 'adam galat bābāwāt Rūmiya, the Arabic translation of Eustratios Argentis's Peri tis psevdhous apsevdhias tou Papa Romis (Brief Epistle against the Pope's Infallibility); ${ }^{27}$ in ${ }_{1747}$, Kitāb al-'Ašā al-Rabbānī (The Book of the Lord's Supper),

$22 \quad$ For details on Patriarch Sylvester's sojourn at the St Spyridon Monastery in Bucharest see I. Feodorov, Tipar pentru creștinii arabi, pp. 231-233.

23 One signed in 1745, a text printed in Romanian (in Bucharest?), is preserved in the Library of the Romanian Academy of Bucharest; cf. BRV, t. II, Bucharest, 1910, p. 84.

24 For an English version of this list see I. Feodorov, "Christian Arabic Texts Printed with Help from the Romanian Principalities in the 18th Century. An Annotated Record", Istros. $X X$, Brăila, 2014, pp. 689-729 (downloadable from the CEEOL website). For a French version see eadem, "Livres arabes chrétiens imprimés par l'aide des Principautés Roumaines au début du XVIII siècle. Répertoire commenté", Chronos. Revue d'histoire de l'Université de Balamand, 34 (2016), pp. 28-33.

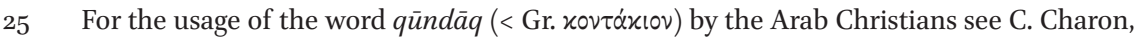
Le Rite byzantin dans les patriarcats melkites, Alexandrie-Antioche-Jérusalem, Rome, 1908, p. 101.

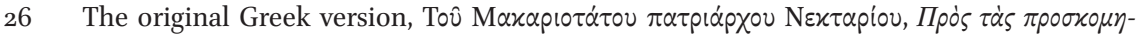

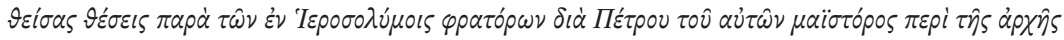

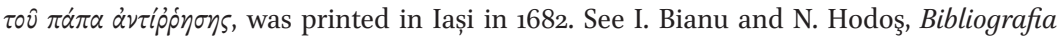
românească veche (or BRV, Romanian Early Printing), t. I. 1508-1716, Bucharest, 1903, pp. 251-258; J. Nasrallah - Fr R. Haddad, Histoire du mouvement littéraire dans l'église melchite du vème au XX'̀me siècle (1724-1800), vol. IV, t. 2, Louvain-Paris, 1989, p. 97.

27 The copy of the Library of the Romanian Academy in Bucharest bears the shelfmark CRV $25^{\circ} \mathrm{C} \&$ D. It was described by I. Bianu and D. Simonescu in BRV, t. IV. Adăogiri și îndreptări (Additions and corrections), Bucharest, 1944, pp. 61-67, 325. 
by Eustratius Argentis, discussing the Mystery of the Eucharist and the controversy between the Orthodox and the Latin about the unleavened bread; and again in 1747, 'A'māl al-muğtami'ayn al-kanisizayn al-mun'aqidayn fi-lQusțanțininya bi-ša'n zuhūr al-kāțūlika bayna șufüf al-masīhiyyìn al-'anțākiyyīn, enclosing the acts of the Synod of Constantinople convened by Patriarch Jeremiah III in 1723 and the Synod of 1727, presided over by Patriarch Paisius, followed by five brief polemic treatises concerning the contradictions between the Orthodox and the Latin dogmas, and a Greek-Orthodox Creed.

There is no information as to the source of the Arabic type used in printing these books in Iași. After he finished, the type was used out, to such an extent that it needed replacement, which made the Patriarch look for a solution in Constantinople and Bucharest. No other book was printed in Arabic in the Romanian Principalities after this episode ended. However, Arabic type was made at the St Spyridon Monastery in Bucharest in 1748-1750, by order of Patriarch Sylvester, under the supervision of Yūsuf Mark, and it was used for printing several service books in Beirut after $1751 .{ }^{28}$

Basic information on these books was provided by J. Th. Zenker, Bibliotheca Orientalis. Manuel de bibliographie orientale, ${ }^{29}$ the Syrian historian 'Īsā Iskandar al-Malüf in an article published in $1911{ }^{30}$ then Joseph Nasrallah and Fr Rachid Haddad in Histoire du mouvement littéraire dans l'église melchite du Vème au XX ${ }^{\text {ème }}$ siècle (1724-1800). ${ }^{31} \mathrm{Of}$ all these titles, in Romania only one is available: the 1746 book that encloses the works of Nektarios and Argentis, described by Dan Simonescu, with the assistance of a Syrian priest, Emil Murakade, ${ }^{32}$ based

28 I. Feodorov, New Data on the Early Arabic Printing in the Levant, pp. 202-205, 208 et seq.

29 Vol. I, Leipzig, 1846, p. 88.

30 'İ.I. al-Ma'ūf, مطبعة رومانية الارثوذوكسية العربية الانطاكية "Maṭbāta rūmāniyya al-'urtwūduksiyya al-'arabiyya al-'anțākiyyā", Al-Ni'ma, 3 (1911), pp. 54-56.

$3^{1} \quad$ J. Nasrallah - Fr R. Haddad, op. cit., pp. 87-89.

32 Beside the translations from Arabic done for BRV, t. IV (pp. 32-34, 38-40, 61-67), Emil Murakade provided information about the early Arabic printed books for Dan Simonescu's articles: "Tipar românesc pentru arabi în secolul al XviıI-lea" ("Romanian Printing for the Arabs in the 18th Century"), in: Cercetări literare publicate de N. Cartojan, Bucharest, 1939, t. III, pp. 1-14, with Annexes on pp. 15-26 and facsimiles on pp. 29-32 (signed together with E. Murakade); "Cărți arabe tipărite de români în secolul al XviıI-lea (1701-1747)" ("Arabic Books Printed by the Romanians in the 18th Century (1701-1747)"), Biserica Ortodoxă Română, LXXXII, 5-6 (1964), pp. 524-561; "Impression de livres arabes et karamanlis en

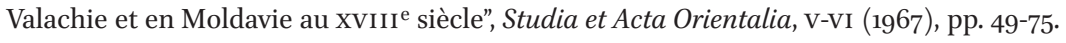
For Emil Murakade's sojourn and activities in Bucharest, see I. Feodorov, "La Damasc, în căutarea unui prieten al României: Părintele Emil Murakade" ("In Damascus, Looking for a Friend of Romania: Father Emil Murakade"), Tabor, Cluj-Napoca, 5 (2015), pp. 74-81. 
on the unique copy of the book preserved at the Library of the Romanian Academy in Bucharest.

\section{The Book of the Divine Liturgies of Iași, 1745}

The Book of the Divine Liturgies printed in 1745 in Iași by Patriarch Sylvester is a re-edition of the Arabic text of the book printed in 1701 by Antim the Iberian and Athanasios Dabbās at the Monastery of Snagov, in Wallachia. The earlier one comprised, on parallel columns, the Greek and the Arabic text. A note placed at the end of the Iași edition indicates that printing was completed on 19 July 1745. Both versions comprise the three Divine Liturgies - of Saint John Chrysostom, St Basil the Great and the Presanctified Gifts - followed by Paremias and Apolyseis for Vespers and Matins. Patriarch Sylvester, in his Foreword, states that the book-printing costs were covered by Ioan Mavrocordat, the prince of Moldavia.

The 1745 edition was first recorded by Julius Theodore Zenker in his Bibliotheca Orientalis. Manuel de bibliographie orientale (vol. I, Leipzig, 1846, p. 88). In his above-mentioned article of 1911, 'Īsā Iskandar al-Ma'ūf mentioned this title in the list of Patriarch Sylvester's books printed in Iași. ${ }^{33}$ The book is men-

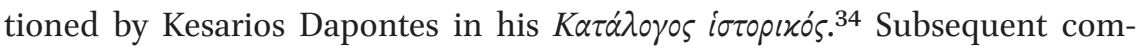
ments were made based on these sources, as this became a rare book. No copy is preserved in Romania. This is probably the reason for not including its title in $B R V$ (Bibliografia românească veche - Bibliography of the Romanian Early Printed Books),, 35 where the authors recorded, as a rule, the books that they were able to study.

The Syrian historian 'Īsā Iskandar al-Ma'lüf stated that he had seen two copies of the 1745 edition at the Monastery of St Tekla in Malūla and one at the Monastery of Șaydnāyā. ${ }^{36}$ A copy is recorded in the library of the Antiochian

'Ī.I. al-Ma'lūf, مطبعة رومانية الارثوذوكسية العبية الانطاكية "Maṭbā‘a rūmāniyya al-'urțūduksiyya al-'arabiyya al-'anțākiyyā", p. 55 . C. Sathas, ibidem; C. Erbiceanu, ibidem.

35 Neither in vol. II. 1508-1830, under the year 1745, nor in vol. IV. Adăogiri și îndreptări (Additions and Corrections). Incidentally, one single other book printed by Sylvester in Moldavia is included in D. Râpă-Buicliu's Bibliografia românească veche. Additamenta, I. 1536-1830, Galați, 200o, p. 253-254: Eustratius Argentis, كَّاب العشاء الرباني Kitāb al-Ašā al-Rabbānī (Book of the Lord's Supper). This new record is based on descriptions collected from sources published after 1964 . 
Greek-Orthodox Church in Damascus. On one of the copies of Ma'lūla there is a note, stating that the book entered its library "during the term of Sylvester, the Patriarch of Antioch".

Incidentally, the editio princeps of the Arabic Book of the Divine Liturgies (Snagov, 1701) is also a rare book: four copies are preserved in Bucharest (only two complete), two in Rome, two in Vienna, one in Paris, Kiev, Athens, Kaslik, Zahle, Șaydnāyā, and one, recently discovered (in November 2018), at the Institute of Oriental Manuscripts in St Petersburg, Russia. The best description of the Snagov Book of the Divine Liturgies is available since 1998 in the online catalogue of the Library of the Romanian Academy (OR B section, first record under "Liturghier").The book structure, described according to the Unicum copy (best of the four owned by this Library), is: [14] + 93 + 253, 37 i.e., 14 unnumbered fol. $\mathrm{r} / \mathrm{v}(=28 \mathrm{pp}$. $)+96 \mathrm{pp} .+253 \mathrm{pp}$., in two sequences of numbering. ${ }^{38}$ This is the copy that I am referring to henceforth. ${ }^{39}$

It is worth mentioning that the Book of the Divine Liturgies was printed again around 1753 in Beirut, in the press installed at the St George Church with the financial support of Šay $\underline{h}$ Nīqūla al-Ğebeylī (or Abū 'Askar, d. 1787). ${ }^{40}$ Information about this book is scarce. Dr Ulrich Jasper Seetzen, who travelled to Syria and Palestine in 1803-1808, was the first to mention this Book of the Divine Liturgies, and seemingly the only one to have examined it. ${ }^{41}$ In the absence of any copies, it is difficult to ascertain the model of this new edition. However, we may presume that it was based on the editio princeps of Snagov, 1701, printed by Antim the Iberian and Athanasios Dabbās, since at the same time a re-edition

Manuscripts. Patriarchal Monastery of Our Lady of Saydnāyā), Damascus, 1986, p. 115-116, no. $150-152$ (3 copies).

Not "[14] f. + 253 pp.", as mentioned by I. Bianu and N. Hodoș in BRV I, Bucharest, 1903, p. 423 .

38 Accordingly, I indicate in my references herewith: "1st seq." and "2nd seq." of numbering.

39 The complete scan of the Unicum of this book (CRV 130) is accessible here: aleph23.

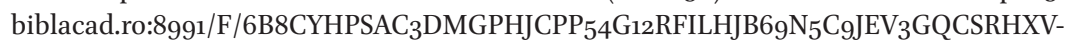
17246 ?func $=$ full-set-set\&set_number $=014523 \&$ set_entry $=000001 \&$ format $=999 . \quad$ Besides the already rich information in the овв online catalogue, a detailed description is available in Antim Ivireanul. Opera tipografică (Antim the Iberian. The Printing Work), coord. Archim. Policarp Chițulescu, ed. D. Bădără, I.M. Croitoru, G. Dumitrescu, and I. Feodorov, Bucharest, 2016, pp. 88-96 (with 11 ill.). A scan of this chapter is accessible at: <https:// ioanafeodorov.academia.edu/>.

40 On the first print press in Beirut see I. Feodorov, Tipar pentru creștinii arabi, pp. 255-26o, and eadem, New Data on the Early Arabic Printing in the Levant, pp. 208-209, 214-216.

41 The information that he gave was repeated by Chr. Fr. Schnurrer in his Bibliotheca Arabica, Halae, 1811, on pp. 383-384, then, citing Chr. Fr. Schnurrer, by P. Deschamps, Dictionnaire de géographie ancienne et moderne à l'usage du libraire et de l'amateur de livres, Paris, 1870, pp. 1182-1183, and by J. Nasrallah, L'Imprimerie au Liban, Beirut-Harissa, 1949, p. 46. 
was made of their other joint work, the Kitāb al-'Urūtūğiyyūn, Book of Hours (Bucharest, 1702, in Greek and Arabic) ${ }^{42}$.

\section{The Book of the Divine Liturgies included in MS 15 of Dayr Sayyidat al-Balamand}

The new information that the present article is intended to convey concerns a printed copy of the Book of the Divine Liturgies that is comprised in a codex preserved at Dayr Sayyidat al-Balamand near Tripoli (Lebanon), with the shelfmark " $M S 15$ ". ${ }^{43}$ The text was made available through the exceptional database of the Hill Museum and Manuscripts Library (vHMML), as an item in the manuscripts collection scanned at Dayr Sayyidat al-Balamand and concisely described for the purpose of the HMML project. ${ }^{44}$ In its catalogue, MS 15 is described as a "Qundaq Gospel Commentary", i.e., a Qondaq or Book of the Divine Liturgies accompanied by comments. It covers 142 pages $(=71 \mathrm{fol} . \mathrm{r} / \mathrm{v})$, numbered in pencil in Arabic numerals, as a manuscript, on the recto page (one figure for every two pages). ${ }^{45}$ The description available online indicates the folio dimensions $19.5 \times 29.5 \mathrm{~cm}$ and a volume thickness of $2.2 . \mathrm{cm}$.

In fact, the codex is made of two texts with no connection between them, one a manuscript text and the other a printed book, with missing pages. ${ }^{46}$

The first section, a manuscript, covers 10 fol. and envelops the second section like a cover. It originally formed a 4 -fol. quire +2 separate fol. at the end: in the current numbering, fol. oo1 $[\mathrm{r} / \mathrm{v}]$ to $002[\mathrm{r} / \mathrm{v}]$ and $07 \mathrm{O}[\mathrm{r} / \mathrm{v}]$ to $\mathrm{O}_{71}[\mathrm{r} / \mathrm{v}]+2$ pages indicated as "00010 - b p" and "ooo10 - $\mathrm{f} \mathrm{p".} \mathrm{The} \mathrm{manuscript} \mathrm{folios} \mathrm{show}$ an original Arabic numbering, seemingly in the same hand and ink as the text,

42 See I. Feodorov, "Livres arabes chrétiens imprimés par l'aide des Principautés Roumaines", pp. 16-18.

43 This codex was brought to my attention by Dmitry Morozov and Nikolay Seleznyov. I am very grateful to both of them for having given me the opportunity to survey it in depth and ascertain its contents, as presented henceforth.

44 In the scan accessible on the vHMML website at: <https://www.vhmml.org/readingRoom/ view/107680> (HMML Project Number BaLA ooo10) the folio numbers of MS 15 are indicated at the bottom of each image, preceded by the HMML project number, labelled: "bala ooo1o". In the description henceforth this pencil numbering is not taken into consideration.

46 I hereby express my gratitude to all those who helped me describe the Book of the Divine Liturgies: Dr. Doru Bădără (Central University Library of Bucharest), Luminița Kövari and Oana Dimitriu (Library of the Romanian Academy in Bucharest), and Mihai Țipău, my colleague at the Institute for South-East European Studies, who kindly read the entire text and suggested improvements. 
starting with Vr (72). The text is handwritten for the greater part in Syriac and the rest in Arabic. The copyist was proficient in both languages and scripts, Syriac and Arabic, seemingly passing with ease from one to the other. This section presents a commentary about the Pharisees' hypocrisy, the story of Jesus walking on water, Peter's original belief and later disbelief. ${ }^{47}$ The author cites several passages of the Gospel of Mark, all in Syriac, except one, given in Arabic. By the looks of it, the manuscript folios, a section of a long text, were bound around the second section (described henceforth) to protect it. In support of this theory is also the position of the two manuscript folios at the end, right after the end of the second section $\left(07 \mathrm{O}[\mathrm{r} / \mathrm{v}]\right.$ to $\left.{ }_{071}[\mathrm{r} / \mathrm{v}]+00010-\mathrm{b} \mathrm{p}\right)$ : they were bound in bottom-up position, as if reading these five pages of text was not considered a priority by the binder.

The second section of the codex, covering fol. $3 \mathrm{r}$ to fol. $65 \mathrm{v}$, encloses an Arabic-type printed book, in the Arabic language: the Book of the Divine Liturgies, the first book that Patriarch Sylvester of Antioch printed in Iași, in 1745. The text covers 126 pages $(=63$ fol. $\mathrm{r} / \mathrm{v}$ ). In $M S 15$ the title page is missing. The printed text has a signature in Cyrillic script (number-value letters) placed under the frame of the printed text, centre-bottom, and visible only on some pages, quite irregularly. ${ }^{48}$ I compared this text with the Unicum at the Library of the Romanian Academy in Bucharest and concluded that the 1745 text is a re-edition of the Arabic text printed in Snagov in 1701 by Antim the Iberian and Athanasios Dabbās, in parallel columns with the Greek Liturgikon.

In the 1745 edition the text begins with a Foreword composed by Patriarch Sylvester, covering four pages (fol. $3 \mathrm{r}$ to $4 \mathrm{v}$ ). It starts with:

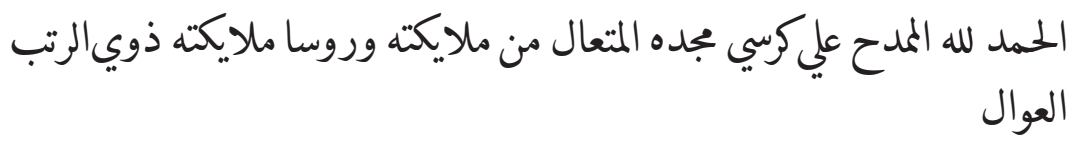

"Praise to the Lord, Who is lauded on the high throne of His glory by His Angels and Archangels, according to their high ranks."

It ends with:

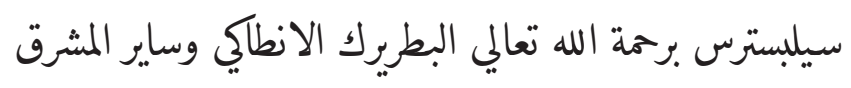

47 I owe the description of the Syriac text to Dr. Ephrem Aboud Ishac, an expert in Syriac studies attached to the vestigia Manuscript Research Center (The University of Graz), to whom I am very grateful.

48 E.g., o1or, o13r, o18r, o25r, o37r. The irregularity may be accountable to the poor state of some pages, where the bottom area, below the frame of the printed text, is not visible. 
"Sylvester, by the grace of God, Patriarch of Antioch and All the East".

Then follows the introductory text of the Book of the Divine Liturgies, preceded by the usual phrase:

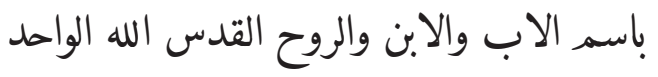

"In the name of the Father, the Son, and the Holy Spirit, One God."

The printed text ends on fol. $065 \mathrm{v}$, close to the completion of the last section, Metalēpsis, which comprises the prayer before the Eucharist. ${ }^{49}$ The last line is the beginning of an additional indication to the celebrating priest: "And when you go to partake [of the Eucharist], secretly say (//end of fol. o65v//, continuing by hand - see below) these verses by Simeon Metaphrastes: 'I now strive to approach the Holy Communion. Do not consume me, O, my Fashioner, ${ }^{50}$ at [the time of my] partaking - for You are Fire consuming the unworthy - but rather purify me of all filth." In the 1701 edition, where this passage is missing, there are four pages of prayers in gratitude after partaking of the Eucharist (only in Arabic), and the final chapters, in Greek and Arabic: a ten-pages section of "Apolyseis for the whole week, to be uttered at Vespers, Matins, and the

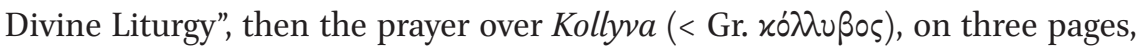
and a final note, on one page, with details about the printing work: its financing by the prince Constantin Brâncoveanu, the printers' names, the place and year of printing. In $M S 15$ the text resumes, copied by hand on seven folios, from fol. $66 \mathrm{r}$ to $69 \mathrm{v}$. After the above-mentioned additional text, the final section is identical to the 1701 version; the copyist probably followed it in a copy of the editio princeps. ${ }^{51}$ The last three words indicate that this book was a donation (waqf) to the Monastery of Balamand (وقف دير البهند). The note probably dates from the time when the printed section was entire, and an independent book, not part of MS 15 .

The text encloses four wood-block engraved icons, three representing the authors of the liturgical texts and the fourth - the icon of the Proskomidia. Two pages, fol. oo6v and o6or, which lost part of the printed text, were repaired by copying the missing text from the 1701 edition (or a manuscript copy, as mentioned before). On fol. o26v, half-way through the Liturgy of St John

49 In the 1701 edition, the corresponding page is 235 (2nd seq.).

$5^{\circ} \quad$ Textually: $\breve{g} \bar{a} b i l<\breve{g} a b a l a=$ to mould, form, shape, fashion sth.

$5^{1} \quad$ The other possibility is that the copyist had access to one of the manuscript copies of Sylvester's revised version, mentioned by J. Nasrallah - Fr. R. Haddad, op. cit., p. 87 . 
Chrysostom, there is a marginal note written in black ink, a prayer for the wellbeing of the monastery Archimandrites and their relatives.

The contents of the printed section can be summed up as follows:

\begin{tabular}{lll}
\hline MS 15 & Book page(s) & Contents \\
folios (bala & in the printed & \\
ooo10-) & section of & \\
& $M S_{15}$ & \\
\hline
\end{tabular}

\begin{tabular}{|c|c|c|}
\hline $003^{r-004 v}$ & $1-4$ & $\begin{array}{l}\text { Foreword by Patriarch Sylvester of } \\
\text { Antioch }\end{array}$ \\
\hline $005^{r-022 r}$ & 5-39 & $\begin{array}{l}\text { Title; order of Saturday evening } \\
\text { together with Litia; order of Sunday } \\
\text { Matins; order of the Proskomidia (with } \\
\text { illustration) and dressing in the } \\
\text { liturgical vestments }\end{array}$ \\
\hline $\mathrm{O} 22 \mathrm{~V}$ & 40 & Icon of St John Chrysostom \\
\hline $023 \mathrm{r}-036 \mathrm{v}$ & $41-68$ & Liturgy of St John Chrysostom \\
\hline o37r & 69 & Blank page \\
\hline $037 \mathrm{v}$ & 70 & Icon of St Basil the Great \\
\hline $038 \mathrm{r}-048 \mathrm{v}$ & $71-92$ & Liturgy of St Basil the Great \\
\hline o49r-o5or & $93-95$ & $\begin{array}{l}\text { Indications on the preparation for the } \\
\text { Liturgy of the Presanctified Gifts, its } \\
\text { chief moments, words to be uttered, } \\
\text { and preparation of the Gifts }\end{array}$ \\
\hline O5ov & 96 & $\begin{array}{l}\text { Icon of St Gregory the Great, the } \\
\text { Dialogist }\end{array}$ \\
\hline $05^{1 r-0}-56 v$ & $97-108$ & Liturgy of the Presanctified Gifts \\
\hline $057 \mathrm{r}-065 \mathrm{v}$ & $109-126$ & $\begin{array}{l}\text { Prayers before partaking of the Holy } \\
\text { Eucharist }\end{array}$ \\
\hline
\end{tabular}

I will refer in what follows to the salient features of the first Arabic book printed in Iași, in 1745, by Patriarch Sylvester of Antioch, in terms of: 1) Contents and language features; 2) Iconography and ornaments.

\subsection{Contents and Language Features}

In the middle of the 18th century, the Book of the Divine Liturgies was, for the Arabic-speaking Byzantine-rite Christians same as for the Romanian ones, the 
most needed Church book. In the Romanian lands, this title was published with the highest frequency and in a large number of copies, both in Slavonic and, especially from the 18th century on, in Romanian. ${ }^{52}$

Patriarch Sylvester asserts in his Foreword to the Iași edition that he had revised in 1744 the text of the 1701 edition and corrected certain language mistakes. The edition of Snagov was the first Arabic text of the Book of the Divine Liturgies ever printed. The manuscript copy that Athanasios Dabbās had brought with him to Bucharest, hoping to have it printed, was an Arabic version revised by the Metropolitan of Aleppo Meletios Karme before being elected as Patriarch of the Church of Antioch (Eftimios II, 1634-1635). Karme had joined the monastic order at the St Sabbas Monastery in the Holy Land, where he had acquired a good knowledge of Greek. He initiated and supervised in 1612-1635 a vast revision activity for the chief liturgical texts used by the Antiochian clergy. Possessing a good mastery of Arabic, Syriac, and Greek, Karme revised the Book of the Divine Liturgies, the Sticherarion, the Typicon, and after 1630 - the Book of Hours and the Euchologion. He also started revising the $\mathrm{Me}$ naion, assisted by his brother, who was a deacon, but did not manage to complete this work before passing away. Some of these books circulated in copies made after the nth-century versions of 'Abdallāh Ibn Faḍl al-Anțākì, one of the first translators and revisers of Arabic liturgical works. To correct the Arabic texts preserved in versions that had been recopied for centuries, Meletios Karme made his revisions based on Greek originals, which allowed him to eliminate those elements that belonged to a very old stratum of the Antiochian rite, as well as the language particularities that differentiated the Church of Antioch from the other heirs of the Byzantine Church. He aspired to a return to Tradition and the uniformity of the Arabic liturgical texts, brought closer to the Greek ones, which were considered a pure reflection of the Byzantine rite. Dr Charbel Nassif, who devoted a chapter of his Ph. D. thesis to the Arabic Euchologion, ${ }^{53}$ noted that the reform plan of the Arabic liturgical books that Meletios Karme followed was driven by five motivations: the fact that Antiochian priests did not master Greek anymore; the shortage of Arabic liturgical books (in manuscript copies, at the time); the presence of dogmatic errors in the texts copied by generation after generation; the necessity to unify the

$5^{2} \quad$ Fr E. Braniște, Liturgica generală cu noțiuni de artă bisericească, arhitectură și pictură creștină, 2nd ed., Bucharest, 1993, pp. 650-652.

53 "L'œuvre du peintre alépin Youssef al-Musawwer. Contribution à la genèse de l'iconographie melkite au XVII ${ }^{\mathrm{e}}$ siècle", Ph. D. thesis defended at Université Paris IV - Sorbonne in 2017. To be published soon. 
church rites; the fact that in the widely-circulated manuscript copies rituals foreign to the Greek-Orthodox traditions had been introduced. ${ }^{54}$

Karme's action was well received by the Antiochian clergy, aware of the urgency to unify the liturgical texts. While travelling through Eastern Europe between 1653 and 1658, Patriarch Makarios III Ibn al-Za'îm had with him a manuscript copy of the Book of the Divine Liturgies revised by his mentor Meletios Karme, hoping to have it printed. ${ }^{55}$ Printing the Arabic church-books in 1701-1711, at Snagov, Bucharest and Aleppo, allowed these texts to be standardised, leading to an accomplishment of Meletios Karme's improvement plan, initiated almost one century before.

The Romanian theologian and historian of the Orthodox Church Fr Ene Braniște stated that in the Romanian printing-culture "every edition was generally improved in connection with its language features. Texts were compared with the Greek originals especially to remove the translation errors present in old editions so that phrases were expressed with more clarity, while a new form of the Typicon indications was adopted." ${ }^{26}$ Revising the text that Athanasios Dabbās had printed, Patriarch Sylvester worked in the same spirit, intending to adapt it to the Church language of his time and bring it closer to the Arabic vernacular of the mid 18th century.

Arabic had replaced Syriac a century before as the liturgical language of the Church of Antioch. ${ }^{57}$ In the 16th century, the clergy still used Syriac and Greek in church services, but the knowledge of these languages diminished under the pressure of Arabic, which had been adopted long before by the entire population of the East-Mediterranean Coast. I recall that, on the threshold of the 17th-18th centuries, Greek was still a vehicle of communication between the Arabic-speaking clergy of Ottoman Syria and that of the Romanian Principalities (and all other territories inhabited by Byzantine-rite Christians). In 1640166o translations of Byzantine and post-Byzantine literature, directly into Arabic, were carried out with increased enthusiasm. ${ }^{58}$ Important figures of the

54 E.g., in his version of the Euchologion Karme comprised only the rituals that were in use in the Church of Antioch - 118 chapters, as compared to the approx. 180 in the ByzantineGreek Euchologion.

55 I. Feodorov, Notes sur les livres et l'imprimerie chez Paul d'Alep, Voyage du Patriarche Macaire III d'Antioche aux Pays Roumains, au 'Pays des Cosaques' et en Russie, in Actes du Symposium International Le Livre. La Roumanie. L'Europe, Bibliothèque Métropolitaine de

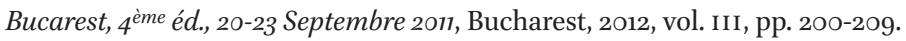

56 Fr E. Braniște, op. cit, p. $65^{2}$.

57 See Alex. Treiger, The Arabic Tradition, in The Orthodox Christian World, ed. A. Casiday, London, 2012, p. 89 et seq.

58 See, e.g., the translations of Makarios III Ibn al-Za'ìm together with his son Paul, recorded by J. Nasrallah, Histoire du mouvement littéraire dans l'église melchite du vème au XXème 
Antiochian hierarchy originated from Greek-language communities, either from North Syria or from the Greek islands. In the first half of the 18th century, Antiochian hierarchs strived to improve their knowledge of Greek, travelling to Constantinople and Mount Athos for this purpose. ${ }^{59}$ Dabbās asserts in his Foreword to the Book of the Divine Liturgies of Snagov that before this book was printed Antiochian priests only uttered the Ekfonises in Greek. The inclusion of Greek passages in the Arabic liturgical books was obviously considered desirable. Fr Kiril Karalevsky (Cyrille Charon) explained that after Syriac was replaced in church service, Greek passages were enclosed in the liturgical texts as a sign of the desire to return to the Byzantine roots of the Divine Liturgies, but this did not go beyond a few Troparia and verses. ${ }^{60}$ The 1701 edition of the Book of the Divine Liturgies comprises a large number of Greek passages, printed in Greek type within the Arabic text, mostly words and prayers uttered at precise moments in the various orders.

The fact that Patriarch Sylvester printed in Iași only the Arabic version of the Book of the Divine Liturgies is proof enough that Greek had vanished from the cult. Undoubtedly, the Patriarch could have asked the skilled typographers of Iași to include the Greek version in his new edition, placing the two versions on parallel columns, as Antim had done in 1701. But Sylvester was printing for the priests of his age. Although he was a native speaker of Greek, the clergy and the flock were, at the time, Arabic-speaking in their vast majority. For this reason, certain words and phrases that had a Greek form in the 1701 edition were changed to an Arabic form in 1745. E.g., the text for the order of the Proskomidia (ترتيب الذبيحة المقدسه), which also encloses the prayers uttered during

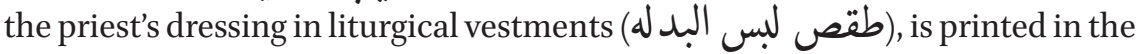
Snagov edition as a continuous Arabic text, with insertions of Tipikon indications in Greek, some translated in Arabic (pp. 41-78, 1st seq.). ${ }^{61}$ In the 1745 edition, the same text is printed only in Arabic (fol. $17 \mathrm{r}$ to $22 \mathrm{r}$ in Ms. 15).

Sylvester's interventions in the text are visible from the beginning of the liturgical text. The opening dedication to God,

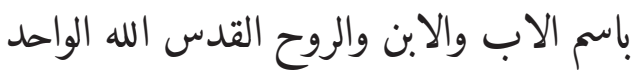

"In the name of the Father, the Son, and the Holy Spirit, One God"

siècle, vol. IV, t. 1, Louvain - Paris, 1979, pp. 89-126.

59 See the case of Sophronios of Kilis, Bishop of Acre, in I. Feodorov, New Data on the Early Arabic Printing in the Levant, pp. 205-206, and J. Nasrallah - Fr R. Haddad, op. cit., especially pp. 96-99.

6 C. Charon, op. cit., p. 172.

$61 \quad$ Antim Ivireanul. Opera tipografică, pp. 91-92. 
was phrased in 1701:

$$
\text { باسم الاب الواحد الابدي الازلي السرمدي وبه نستعين }
$$

In 1745 the title, printed in red ink on fol. oo5r, is:

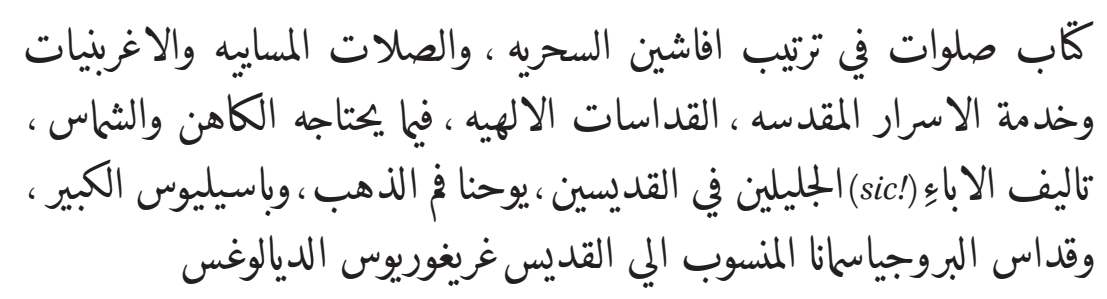

"The Book of Services [Euchologion?] containing the order of the prayers required for Matins, the evening service and Vigils and the service of the Holy Mysteries, [i.e.,] the Divine Liturgies, such as they are necessary for the priest and the deacon, which were composed by the Holy Hierarchs St John Chrysostom and Basil the Great, and the Liturgy of the Presanctified Gifts, ascribed to St Gregory the Dialogist." In the 1701 edition the title, also in red ink, goes:

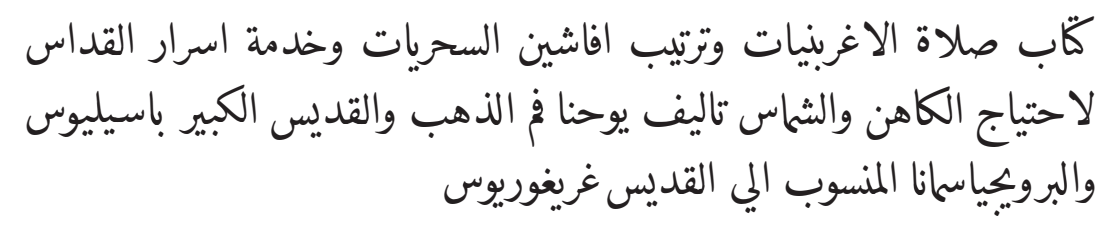

"Book of the prayer of Vigils, the order of the Matins and that of the Divine Liturgy, for the priest's and the deacon's needs, composed by St John Chrysostom and the Great Saint Basil, and the Liturgy of the Presanctified Gifts, ascribed to St Gregory."

The title that follows on the same page in the 1745 edition, in much larger type and black ink, is The Vigil service, صاغ ة الاغرين... In the 1701 edition this title, in red ink, is placed at the head of the right-hand column, dedicated to the Arabic text. The content henceforth is almost identical, with a few variations accountable to Sylvester's revision.

At the beginning of the Vespers service, details are given about the ritual of dressing in liturgical vestments and preparing for service, the prayers and words to be uttered at this time. Only the first phrase: 
"The seven prayers of Vespers. These prayers are uttered during the evening service of all the days of the year except the Bright Week"62

is slightly different.

In 1701 (p. 3, 1st seq.):

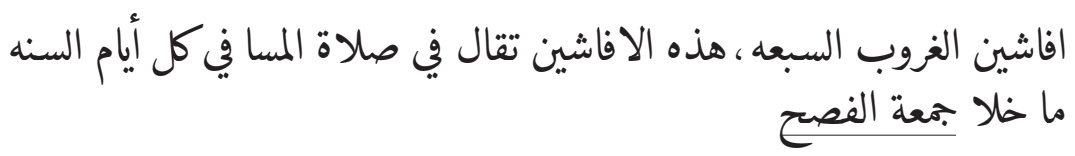

In 1745 (fol. oo5r):

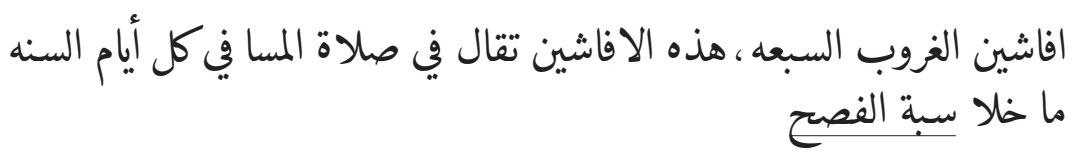

The Metalepsis prayer, close to the end of the book, has the title: 1701 (p. 207, 2nd seq.):

$$
\text { طقس صلاة المطالبسي قبل تناول الاسرار }
$$

"The order of the Metalêpsis before partaking of the Mysteries." 1745 (fol. 057r):

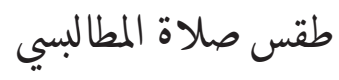

"The order of the Metalêpsis."

"The Afterlife" of the 1701 edition (حاة الابد) becomes, in 1745, "Eternal Life" (الحياة ابدية). St Simeon Metaphrastes is named in 1701 "The Recluse", while in 1745 his Greek name is given in Arabic transcription, Al-Mìțäfrāstīs (الميطافزاستيس).

A theologian scholar with a good knowledge of Arabic will hopefully compare the two Arabic versions of the Divine Liturgies printed in 1701 and 1745, to highlight all the interventions that Patriarch Sylvester achieved when printing the book in Iași and to assess their theological - or merely philological - significance for the renewal of the liturgical texts used by the Arabic-speaking

62 Or Paschal Week, the week after Pascha. Fr Alexander Treiger (Dalhousie University) helped me refine the English translation in several passages. Thank you again, Father! 
Orthodox Christians in the first half of the 18th century. This will help ascertain Patriarch Sylvester's place in the long line of hierarchs of the Antiochian Church who revised them, from 'Abdallāh Ibn Faḍl to Meletios Karme, Athanasios Dabbās, and Patriarch Sylvester himself.

\subsection{Iconography and ornaments}

The book is printed in black ink and, to a lesser extent, in red: Tipikon indications for the priest and the deacon, the first word of certain phrases uttered by them, explanations of important liturgical moments. The printed text is enclosed in a simple black frame, doubled at the top to encompass a running title. Under the frame, at the lower left bottom of all verso folios, a catch-word is placed, in black or red ink. This element seems to have followed the model of Antim the Iberian's books, but the richness of typographic ornaments in his works is absent from this book. In the 1745 edition, the type is in two sizes, small for the text, large for titles and introductory words, the latter probably printed with engraved wood-blocks. The chapter titles are part of the text lines. The pages were printed in two successive movements, first the black text was printed, then the red one. Often, black and red lines are not aligned, as if the second movement was not done with great precision. The Snagov printers' superior skill is quite obvious: they had no trouble to align perfectly the black text with the red one.

An important aspect is that of the printed engravings of icons and ornaments in the 1745 Book of the Divine Liturgies. The Deisis icon that was present in the 1701 edition is missing here. ${ }^{63}$ Three Saints' icons are present, with their names printed in Greek type: St John Chrysostom, St Basil the Great and St Gregory the Great, each placed before the onset of the Liturgy that he composed. I have not been able to identify the origin nor the model of these icons. On the other hand, the icon of the Proskomidia (fol. orgr) is identical with the one in the 1701 edition of Snagov. ${ }^{64}$ Therefore, a new wood-block was carved for it, with a different shape of letters, but the same design and graphic elements.

In 1745 there are vignettes only at the end of the main sections. Oana Dimitriu (Library of the Romanian Academy in Bucharest) identified almost all of these vignettes in other books printed in Iași between 1743 and 1757, besides one in the Gospels printed by Athanasios Dabbās in Aleppo, in 1708. Apparently, one of the vignettes was designed in the print press of Duca Sotiriovici, a Greek private printer of Iași (who signed "The Printer of Thassos"). He used this vignette again in a Book of the Divine Liturgies that he printed in Romanian

63 Antim Ivireanul. Opera tipografică, p. 93 (reproduction).

64 Ibidem, p. 91 (reproduction). 
in $1747 .{ }^{65}$ Some vignettes in Sylvester's book may have been made especially for him, and then remained in the presses of Iași to be used again later, in Romanian books. One of the vignettes appeared before Sylvester's Book of the Divine Liturgies, in a book printed in Moschopolis ${ }^{66}$ in 1742: The Service of St Clement of Ohrid, printed by Hieromonk Gregorios Constantinidis. If Sylvester obtained ornamental wood-blocks from Moschopolis, could that have been also the source of the Saints' icons? Moreover, could the Arabic type have also come from Moschopolis? ${ }^{27}$ These are intriguing directions of investigation, worth following up.

Remarkably, the same tool seems to have been used to print one of the ornamental elements: the complex 4-rays star, or square cross, ending in 3 leafshapes, which is present both in the 1745 Book of the Divine Liturgies of Iași and the Psalter printed in Beirut in $175^{2 .}{ }^{68}$ This printing tool could have travelled from Iași to Bucharest and then to Beirut, together with the Arabic types made at the St Spyridon Monastery under the supervision of Yūsuf Mark.

The circulation of typographic material across the Byzantine-rite Christian lands is, in itself, a fascinating field of research, which reveals the existence of another "Orthodox Commonwealth", that of the church-books printers and print presses. Furthermore, printing programmes (lists and sequence of titles printed) are quite similar all across the Greek-Orthodox realm. Incidentally, the same harmony of devotion and creativity is reflected in Paul of Aleppo's Journal, as the Antiochian Archdeacon witnessed its manifold forms throughout his long journey in East-European Orthodox countries, while accompanying his father, Patriarch Makarios III (1653-1658).

The new information that the present contribution provides will need to be enriched through an in-depth study of both contents and form of the Book of the Divine Liturgies printed in 1745 in Iași by Patriarch Sylvester of Antioch. This will give more clarity to the exceptional works that he accomplished with help from the princes and printers of Moldavia and Wallachia, which he continued after 175 o by supporting the foundation and activity of the first Greek-Orthodox print press of Beirut.

65 Dumnezeeştile şi Sfintele Liturghii, a celor dintru Sfinţi Părinţilor noştri, a lui Ioan Zlatoust, a lui Vasilie cel Mare şi a Prejdesşteniii, Iași, 1747, 246 pp. I owe this remark to Fr Archim. Policarp Chițulescu.

66 Alb. Voskopojë, Gr. Moбхó $\pi 0 \lambda ı$, today a village in South-East Albania, was a flourishing Ottoman city during the 18 th century (c. 6o,ooo inhabitants in 176o), and home to the first print press of the Balkans. See M.D. Peyfuss, Die aromunische Frage, Wien-Köln-Graz, 1974.

67 The Greek press of Moschopolis was active in 1731-1769. See C.C. Giurescu, Istoria românilor (History of the Romanians), vol. III/2, Bucharest, 1946, pp. 914-915; M.D. Peyfuss, Die Druckerei von Moschopolis, 1731-1769, Wien-Köln, 1989.

See I. Feodorov, New Data on the Early Arabic Printing in the Levant, p. 220, Fig. 2 and 13. 